\title{
Consensus
}

Volume 21

Issue 1 Women and Men in Theological Education:

Article 20

Exploring the Present, Creating the Future

5-1-1995

\section{Christendom and Christianity in the Middle Ages: The Relations between Religion, Church, and Society}

Peter C. Erb

Follow this and additional works at: http://scholars.wlu.ca/consensus

\section{Recommended Citation}

Erb, Peter C. (1995) "Christendom and Christianity in the Middle Ages: The Relations between Religion, Church, and Society," Consensus: Vol. 21 : Iss. 1 , Article 20.

Available at: http://scholars.wlu.ca/consensus/vol21/iss1/20

This Book Reviews is brought to you for free and open access by Scholars Commons @ Laurier. It has been accepted for inclusion in Consensus by an authorized editor of Scholars Commons @ Laurier. For more information, please contact scholarscommons@wlu.ca. 


\section{Christendom and Christianity in the Middle Ages: The Relations between Religion, Church, and Society Adriaan H. Bredero}

Translated by Reinder Bruinsma

Grand Rapids, MI: William B. Eerdmans, 1994 xiii $+402 \mathrm{pp}$.

Translated from the 1987 second edition of a Dutch original (the first edition was published a year earlier), Christendom and Christianity is a collection of eleven previously published studies. The purpose of their republication as a group Bredero, an emeritus professor of the Free University of Amsterdam, makes clear in his preface. As one "who confesses this faith and is a member of this Church" (ix) the author is convinced that without the process of "continual acculturation, the experience of Christian faith has no future in society. For the promotion of this aggiornamento, the traditions of the Christian Church must continually be cleansed and purified from the nonessential additions of earlier acculturations. This task is unworkable without historical reflection" (viii-ix). What should be cleansed from the tradition and what "valuable elements" of "the essential Christian tradition" are to be retained in a purified form, however, is not always clear in the stimulating essays which make up the work, nor does Bredero take up explicitly the distinction between 'Christianity' and 'Christendom' which he flags in his title. How far is the Church shaped by the society in which it finds itself and by earlier misdirections in its own life, and in what degree can she in turn redirect social constructs? In regard to such questions, that is, in its delineation of the problem of the development of Christian life, however, the volume remains unsatisfactory.

Nevertheless, Bredero's studies deserve close reading, requiring readers to consider aspects of medieval life, not always commented on in other studies. The problem of Christian views of sainthood is one to which Bredero returns with regularity. What is the relation, he asks in his first study on "Religion and Church in Medieval Society" (pp. 1-52), between earlier pagan nobles' concern with ancestor veneration and the Christian veneration of saints? Later in the volume in "Saints and Sainthood" (pp. 151-197) he directs attention to the way in which the canonization process was redirected from a local process to one centred in Rome and how the veneration of the saints was tied to the authority of the Church, and in "The Beginnings of the Franciscan Movement and the Canonization of its Founder" (pp. 246-273), he discusses the use made of the canonization of St. Francis in determining and as determined by early developments and debates in the Franciscan movement. In his final chapter on "Religious Life in the Low Countries" (pp. 319-375) he outlines the way in which Christian concepts of God shifted as the role of the saints became ever more pronounced.

Whereas the practice of venerating saints in the middle ages is often explained by Bredero sociologically and generally not to the credit of those 
practising it (Is this one of the elements of the Christian tradition which he wishes cleansed or purified?), the bishops' attempts to control violence in the 'Peace of God' movement is treated much more positively and considered as a possible "turning point in medieval society" (pp. 105-129). In his discussion of this movement Bredero's treatment carries an implicit as well as an explicit criticism of the upper classes in medieval society. This same pattern is evident in his final study on religion in the low countries in which he explains much of the anticlericalism evident at the close of the middle ages as arising in a context of the bilingual culture of the time. Likewise, he makes a very good case that the lay status of the 'reformer' Henry of Lausanne was in all likelihood the primary issue in the charge of heresy laid against him ("Heresy and Church Reform", pp. 198-224).

Whether or not one wishes to explain the Crusades on the principle that a pilgrimage to Jerusalem had developed in the earlier medieval period as the only solution open for persons facing 'insoluble situations', Bredero's reflections on "Jerusalem in the West" (pp. 79-104) is stimulating reading, as are his arguments demonstrating Pope Urban's initial concern with helping Byzantium against the Turks and the manner in which this was shifted, on the basis of public reaction, to a Crusade to free Jerusalem itself. Above all, readers will wish to pay close attention to his careful discussion of "AntiJewish Sentiment in Medieval Society" (pp. 274-318) and his study of the way in which theology played and did not play a role in its growth.

For readers interested in historiography, Bredero uses the 'history of mentalities' method while at the same time his critique of the approach must be noted (see pp. 53-78).

Peter C. Erb

Wilfrid Laurier University

\section{Faithful Persuasion: In Aid of a Rhetoric of Christian Theology \\ David S. Cunningham}

Notre Dame: University of Notre Dame Press, 1991 xviii +312 pp.

This is a fascinating, though difficult, book. The author is a theologian (Assistant Professor of Theology at the University of St. Thomas, St. Paul, $\mathrm{MN}$ ) who is also trained in communication studies. Out of these two disciplines he writes a treatise in theological method. Christian theological discourse, he writes, is composed of arguments in the forms-and sometimes in the guises-of propositions, directions, exhortations, prophecies, commands, etc. But theological arguments can always be countered; we do not possess ultimate certainty. Therefore he suggests the alternative of 